\title{
THE
}

\section{Competitor Avoidance Drives Within-Host Feeding Site Selection in a Passively-Dispersed Herbivore}

\author{
Sara Gomez \\ Liahna Gonda-King \\ Colin M. Orians \\ Evan L. Preisser \\ University of Rhode Island, preisser@uri.edu
}

Follow this and additional works at: https://digitalcommons.uri.edu/bio_facpubs

Terms of Use

All rights reserved under copyright.

\section{Citation/Publisher Attribution}

Gomez, S., Gonda-King, L., Orians, C. M., \& Preisser, E. L. (2014). Competitor Avoidance Drives Within-Host Feeding Site Selection in a Passively-Dispersed Herbivore. Ecological Entomology, 39(1), 10-16.

Available at: http://dx.doi.org/10.1111/een.12059

This Article is brought to you for free and open access by the Biological Sciences at DigitalCommons@URI. It has been accepted for inclusion in Biological Sciences Faculty Publications by an authorized administrator of DigitalCommons@URI. For more information, please contact digitalcommons-group@uri.edu. 


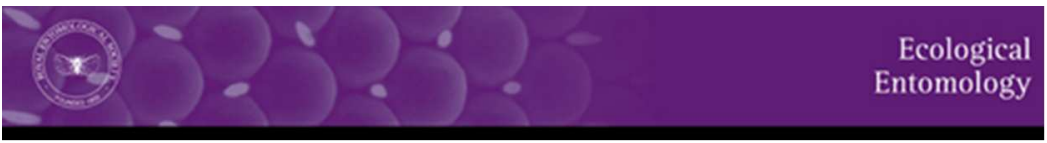

\section{Competitor avoidance drives within-host feeding site selection in a passively-dispersed herbivore}

\begin{tabular}{|r|l|}
\hline Journal: & Ecological Entomology \\
\hline Manuscript ID: & Draft \\
\hline Manuscript Type: & Original Article \\
\hline Date Submitted by the Author: & n/a \\
\hline Complete List of Authors: & $\begin{array}{l}\text { Gomez, Sara; University of Rhode Island, Biological Sciences } \\
\text { Gonda-King, Liahna; University of Rhode Island, Biological Sciences } \\
\text { Orians, Colin; Tufts University, Biology } \\
\text { Preisser, Evan; University of Rhode Island, Biological Sciences }\end{array}$ \\
\hline Keywords: & $\begin{array}{l}\text { preference, within-host selection, choice tests, sessile herbivores, plant- } \\
\text { insect interactions }\end{array}$ \\
\hline
\end{tabular}


Competitor avoidance drives within-host feeding site selection in a passively-dispersed herbivore

\section{Authors:}

Sara Gómez ${ }^{* 1,2}$, Liahna Gonda-King ${ }^{1}$, Colin M. Orians ${ }^{2}$ and Evan L. Preisser ${ }^{1}$

Addresses:

${ }^{1}$ Department of Biological Sciences, University of Rhode Island, 9 E. Alumni Ave., Kingston, RI, USA 02881

${ }^{2}$ Department of Biology, Tufts University, 163 Packard Ave., Medford, MA, USA 02155

\section{Correspondence:}

Sara Gómez

Department of Biological Sciences

University of Rhode Island

9 E. Alumni Ave.

Kingston, RI, USA 02881

Email: saracocogomez@gmail.com

Phone: 1-617-627-4036

Fax: 617-627-3805

Running title: Within-host selection by a sessile herbivore

Key words: female choice, within-host selection, preference, performance, choice tests, sessile herbivores 


\section{Abstract}

2 1. Evolutionary theory predicts that ovipositing females that can actively disperse should

3 select hosts that increase offspring performance. However, for organisms that are exclusively

4 passively-dispersed feeding site selection is only possible at the within-host level. This should be

5 particularly important for their offspring which have strong temporal and spatial dispersal

6 constraints within a host. Such constraints will be likely magnified by tissue quality

7 heterogeneity caused by competing herbivores.

8 2. We investigated within-host feeding site selection of passively-dispersed neonates of a

9 sessile herbivore, the hemlock woolly adelgid (Adelges tsugae Annand) when it shares its eastern

10 hemlock (Tsuga canadensis Carrière) host, with another sessile herbivore, the elongate hemlock

11 scale (Fiorinia externa Ferris). Within-host feeding site selection was studied at the (a) shoot

12 level (with or without $F$. externa) using choice tests and (b) needle level by scoring insect

13 presence in field surveys.

14 3. A. tsugae avoided F. externa-colonized foliage in both the choice tests and field surveys.

15 Since $A$. tsugae has no efficient predators or parasitoids in the study area, we conclude that our

16 results are due to the presence of the competing herbivore.

17 4. Even though A. tsugae cannot actively disperse among hosts, we showed that within-host

18 feeding site selection is an important mechanism to minimize the co-occurrence with a

19 competing herbivore that has known negative impacts on A. tsugae population densities.

20 Studying within-host feeding site selection in a multiple-species context could assist in

21 understanding and predicting the impact of destructive pests such as A. tsugae and the co-

22 evolution with their novel hosts. 


\section{Introduction}

Evolutionary theory predicts that ovipositing females capable of discriminating between

26

27

hosts should lay eggs on those hosts that increase the performance of their offspring (Thompson, 1988; Gripenberg et al., 2010). Most studies on herbivore behavior to date have focused on quality differences at the whole-plant level, comparing adult and/or offspring's preference among different genotypes or phenotypes within a plant species and the relationship between preference and offspring performance (Horner \& Abrahamson, 1992; van Leur et al., 2008; Kleine \& Müller, 2011; Nyman et al., 2011; Soler et al., 2012). Although selecting a highquality host is an important first step in maximizing the performance of future offspring, assessing multiple hosts is impossible for some organisms such as passively-dispersed herbivores. As a result, the selection of suitable feeding locations for such organisms is only possible at the within-host level. Because of ubiquitous within-plant heterogeneity in food quality (Shelton, 2004) and its potential impact on plant-herbivore interactions (Awmack \& Leather, 2002), the ability to select feeding sites within a given host may prove crucial to offspring performance. Evidence shows that herbivores display different preferences between tissues within a host and this can be affected by prior herbivory or other factors extrinsic to the host plant (McAuslane \& Alborn, 2000; Anderson \& Agrell, 2005; Gómez et al., 2007; 2008). In the case of passively-dispersed organisms, we expect they will be subjected to particularly strong selective pressure to evolve mechanisms to discriminate quality differences within the host plant upon landing. To our knowledge, not much is known about preference of passively-dispersed herbivores and the link to offspring performance.

Within a given host, variation in resource quality (and subsequent herbivore preference) can be driven by ontogenetic differences in the foliage. Young foliage is richer in nitrogen and 
47 water content (Mattson, 1980) and usually more palatable than older foliage (Coley \& Barone,

48 1996; Fenner et al., 1999; Gómez et al., 2008). Variation in within-host resource quality can also

49 be affected by the presence of other conspecific or heterospecific herbivores. Feeding by

50 competing herbivores can change host quality via altered resource concentration and

51 composition and/or the induction of defense compounds (Karban \& Baldwin, 1997). These

52 changes can be especially important in interactions between temporally-separated herbivore

53 species. Later-arriving herbivores can experience suboptimal growth and development on a host

54 that has suffered prior herbivory (Inbar et al., 1999; Soler et al., 2007) because changes in

55 foliage quality can persist over extended periods of times (Gómez et al., 2010; Underwood, 56 2012).

57 Within-host feeding site selection is especially important for herbivores whose active 58 dispersal within a host is constrained by spatial and/or temporal limitations (Burstein \& Wool, 59 1993). Herbivores with limited spatial mobility across all life stages might experience strong intraspecific competition due to limited resource availability. Similarly, time-limited dispersers,

61 such as those that suffer high mortality rates within hours after hatching (Itioka \& Inoue, 1991)

62 will be forced to settle in suboptimal feeding sites if a suitable location is not found after an 63 initial habitat discrimination phase is over (Ward 1987). Such spatial and temporal constraints 64 apply to the hemlock woolly adelgid (Adelges tsugae Annand). A. tsugae is a destructive nonnative hemipteran pest introduced to the eastern United States from Japan. It is currently present

66 in 18 states, covering over $45 \%$ of the eastern hemlock's range (Morin et al., 2011). In the

67 invaded range, A. tsugae feeds exclusively on the native eastern and Carolina hemlocks (Tsuga canadensis Carrière and T. caroliniana Engelm, respectively), killing its hosts in as little as four 69 years (McClure, 1991). Stands of these long-lived and shade-tolerant conifers create cool and 
70

71

72

73

74

75

76

77

78

79

80

81

82

83

84

85

86

87

88

89

90

91

92

moist microclimates, critical habitat for a wide range of plant and animal species (Orwig et al., 2012). The invasion by A. tsugae is devastating hemlock forests and dramatically altering the surrounding forest ecosystems (Orwig \& Foster, 1998; Jenkins et al., 1999; Stadler et al., 2005; Cobb, 2010). Because viable $A$. tsugae neonates ('crawlers') in the invaded range are wingless, between-host movement of $A$. tsugae occurs via passive dispersal by wind or animals (McClure, 1991; Turner et al., 2011). A. tsugae dispersal is also temporally limited since crawlers are only mobile for several days; once they settle and begin feeding, they are sessile for the remainder of their life cycle, including the mature stages (McClure, 1987). Despite the limitations imposed on between-host dispersal, the newly-hatched crawlers are mobile and capable of active within-host dispersal, typically settling on the youngest hemlock foliage (McClure, 1989). Because sessile $A$. tsugae adults must oviposit in situ, within-host selection of feeding sites by the newly-hatched crawlers may be crucial for their survival and future fitness.

In its invaded range, $A$. tsugae frequently co-occurs on eastern hemlock with a second nonnative hemipteran pest, the elongate hemlock scale (Fiorinia externa Ferris). A. tsugae and $F$. externa overlap throughout much of their invaded range, and are found in the same hemlock stands and on the same individual trees (Preisser et al., 2008). F. externa also feeds preferentially on eastern hemlock and, like A. tsugae, continues to expand its invaded range (Preisser et al., 2008; 2011). At low to moderate densities, F. externa has minimal impacts on its host (MillerPierce et al., 2010; Radville et al., 2011; Gonda-King et al., 2012); at high densities, however, it may be able to kill already-stressed trees (McClure, 1980). There is strong evidence of interspecific competition between $A$. tsugae and F. externa (Preisser \& Elkinton, 2008). Because A. tsugae crawlers are produced mid-summer, 1-2 months after $F$. externa crawlers have settled and begun to feed, F. externa-induced changes in host quality could alter $A$. tsugae performance. 
93 This hypothesis is consistent with the results of a previous study showing a $40 \%$ decrease in $A$.

94 tsugae population density in trees previously infested with $F$. externa for two years (Miller-

95 Pierce \& Preisser, 2012). If this difference in A. tsugae performance can alter its settling

96 behavior, a selective advantage will accrue to crawlers capable of detecting and avoiding $F$.

97 externa-infested foliage within a host.

Here we examine tissue selection and distribution of $A$. tsugae crawlers in the presence and absence of F. externa. Because crawlers are small, few studies have explored patterns of

100

101

102

103

104

105

106

107

108

109

distribution within or between hosts (but see Evans \& Gregoire, 2007, Turner et al., 2011), and to our knowledge no previous studies have addressed active within-host feeding site selection.

Because adult $A$. tsugae have no effective predators in the invaded range (Wallace \& Hain, 2000; Havill et al. 2011), within-tree crawler movement is likely driven by the need to find a permanent feeding site and by the site-specific likelihood of competition with other herbivores. Specifically, we hypothesized that $A$. tsugae prefers uninfested eastern hemlock foliage over $F$. externa-infested foliage. We tested our hypothesis by conducting laboratory choice tests and field surveys.

\section{Materials and methods}

Herbivores: A. tsugae has two generations a year in its invaded range (McClure, 1987).

Briefly, the April-to-June progrediens generation emerges in early spring and settles on previously-produced hemlock foliage, where it produces $\sim 75$ eggs/female. In contrast, crawlers from the July-to-April sistens generation settle on newly-produced foliage in mid-summer. They aestivate until late fall, then feed throughout the winter, producing $\sim 300$ eggs/female that will become the next progrediens generation. $F$. externa has only one generation in the northern part 
116 of the invaded range; $F$. externa crawlers emerge in late spring and are the first herbivores to 117 settle on newly-produced hemlock foliage (Abell, 2010). The mobile F. externa crawlers also 118 settle on young foliage and reduce host nitrogen levels (McClure, 1980; Gómez et al., 2012).

119 While $A$. tsugae feeds at the base of hemlock needles by inserting its stylet bundle into ray 120 parenchyma cells at the base of the needle cushion (Young et al., 1995), F. externa crawlers 121 settle on the underside of the needles, where they suck fluids from the mesophyll cells (McClure, 122 1980). Both herbivores' crawlers remain sessile once they settle.

Laboratory choice tests: We conducted choice tests to test whether A. tsugae crawlers 124 showed preference for uninfested vs. F. externa-infested foliage within the same tree. In April 1252012 , forty-seven eastern hemlocks naturally infested with $F$. externa were haphazardly selected 126 in the Middlesex Fells Reservation (Winchester, MA). In each tree, two $\sim 5 \mathrm{~cm}$ shoots produced 127 during the previous growing season were selected, one collected from an uninfested branch and 128 the other having at least five adult $F$. externa settled on the needles ( $=47$ replicates). All of the 129 selected foliage was carefully inspected for the presence of $A$. tsugae or any other non- $F$. externa 130 herbivores; there was no evidence of $A$. tsugae or other herbivores on any of the shoots.

In addition to investigate $A$. tsugae preference in naturally-infested trees, we conducted a

132 second set of laboratory choice tests using foliage sources from nursery-purchased trees to 133 control for unknown factors governing $F$. externa infestation in the field. These choice tests were 134 conducted following the same procedure as above but using uninfested and infested foliage 135 (minimum two scale present) from eastern hemlock saplings manually inoculated yearly with $F$. 136 externa in June 2011 and 2012. The saplings were planted in the understory of a mixed conifer-

137 deciduous forest in Kingston, Rhode Island. By enforcing the infestation of $F$. externa on a given 138 set of experimental trees rather than using naturally-infested trees we can rule out the possibility 
139 that the $F$. externa foliage used in the choice tests were successfully infested by $F$. externa due to 140 unknown traits of the host rather than by chance and the possibility that A. tsugae behavioral 141 patterns in feeding site selection were due to innate differences in preference/survival across

142 hosts (or tissues within hosts) by these two insects. In a subset of those tests $(\mathrm{n}=30), F$. externa 143 remained intact on the infested foliage, while in a second subset $(n=32) F$. externa was manually 144 removed from the foliage to determine whether $A$. tsugae's preference is driven by the physical 145 presence of the scale or by F. externa-induced changes in the foliage quality.

In all choice tests, the base of each shoot was placed inside an eppendorf tube with a

147 pierced lid filled with deionized water to avoid desiccation. Both tubes were taped to the bottom

148 lid of a $9 \mathrm{~cm}$ diameter petri dish. Eastern hemlock foliage with $A$. tsugae egg masses was

149 collected from naturally-infested trees and a small stem fragment with three A. tsugae egg 150 masses was placed inside each petri dish touching both shoots (Fig. 1b). The petri dishes were 151 closed and sealed with parafilm and placed on their sides so that the shoots were in an upright 152 position at $21^{\circ} \mathrm{C}$ and natural light conditions. We inspected each petri dish daily for the presence 153 of A. tsugae crawlers. Once A. tsugae crawlers were detected, the inoculants were removed and 154 the crawlers allowed to choose between the two foliage types. Seven days after A. tsugae 155 crawlers were first detected, the number of $A$. tsugae crawlers on each shoot was counted and the 156 percentage of crawlers on each choice was calculated. A sign test was used to assess whether $A$. 157 tsugae crawlers prefer uninfested foliage by comparing the number of replicates with a higher 158 percentage of crawlers on uninfested versus $F$. externa-infested foliage. The second set of choice 159 tests (experimental trees) was analyzed by using a repeated measures ANOVA on the amount of 160 crawlers present on either choice at the end of the test, using infestation by $F$. externa (uninfested 
161 vs infested foliage) as the within-subjects factor and the removal of $F$. externa from the infested 162 foliage (yes/no) as the between-subjects factor.

Field surveys: We conducted three surveys of $A$. tsugae preference in the field. Three

164 hemlock stands were selected based on their moderate densities of naturally-occurring A. tsugae 165 and F. externa (11-100 insects/m branch) as shown by 2011 field surveys (Preisser et al., 2011).

166 The stands were located in Massachusetts (Belchertown and Hampden; sampled on June 21 ${ }^{\text {st }}$, 167 2012) and Connecticut (Suffield; sampled on July $2^{\text {nd }}, 2012$ ). In each site we selected 25 trees 168 infested with both insects. In each tree, we selected two $\sim 5 \mathrm{~cm}$ new-growth shoots (i.e., produced 169 during the 2012 growing season) that were infested with at least three $A$. tsugae and three $F$. 170 externa individuals. We counted the number of needles on each shoot with neither insect, $A$.

171 tsugae only, F. externa only, or both insects. The results from the two shoots per tree were 172 averaged and the expected distribution of needles in each category analyzed using a 2x2 173 contingency table. Because there were no statistical differences among sites (Likelihood ratio 174 test; site effect: $\left.\chi^{2}=0.9261, \mathrm{P}=0.629\right)$, data from the three sites were pooled in the analysis.

\section{Results}

Laboratory choice tests: A. tsugae crawlers chose uninfested foliage over F. externa-

178 infested foliage from the same tree in both naturally- and artificially-infested with $F$. externa 179 trees. In choice tests using naturally-infested trees, 32 of $47(68 \%)$ choice tests, the majority of $A$. 180 tsugae crawlers were present on the uninfested foliage (one-tailed Sign test $\mathrm{P}=0.015$; Fig 1a).

181 Although there was considerable variation in the percentage of $A$. tsugae crawlers choosing 182 uninfested foliage, 23 of 47 choice tests had between $51-75 \%$ of crawlers on the uninfested 183 foliage (Fig 1c). Interestingly, the percentage of $A$. tsugae crawlers on F. externa-infested foliage 
184 was not correlated with the amount of $F$. externa present on the foliage (Pearson correlation $=$ $1850.087, \mathrm{P}=0.561 ;$ Fig $1 \mathrm{~d})$. In choice tests using foliage from experimentally inoculated trees, $A$. 186 tsugae crawlers also exhibited an overall preference for uninfested foliage (Insect infestation $\mathrm{P}$ $187<0.0001$ ), regardless of whether F. externa was left intact on the foliage or manually removed 188 (Insect infestation x Insect removal P = 0.194; Fig 2).

Field surveys: Our field surveys found that $A$. tsugae and $F$. externa co-occurred less often 190 than expected $\left(\chi^{2}=19.04, \mathrm{P}<0.0001\right.$; Table 1$)$. Had A. tsugae been randomly distributed with 191 respect to $F$. externa, 3.1\% of needles should have contained both insects. Our results show that 192 A. tsugae and F. externa only co-occurred on $1.8 \%$ of needles, meaning that the observed value 193 was $42 \%$ lower than expected. Conversely, A. tsugae and F. externa occurred alone more often than expected if both species were randomly distributed with respect to the other.

\section{Discussion}

We found both experimental and survey evidence for active within-host feeding site selection in Adelges tsugae. Specifically, we found that $A$. tsugae crawlers preferred foliage that lacks the competing herbivore $F$. externa in both laboratory choice tests and field surveys of naturally-infested trees. The lower preference for F. externa-infested foliage was driven by plantmediated changes on the foliage caused by $F$. externa's attack rather than the physical presence of this insect. This demonstrates that relying on passive between-host dispersal does not preclude A. tsugae (and, presumably, many other small-bodied insects) from actively choosing a suitable feeding site within a given host. 
207 such as nutrient availability and by biotic factors such competing herbivores (Cronin \& 208 Abrahamson, 1999). While differences in host quality are important for all herbivores, they are 209 perhaps most critical for sessile species that must quickly assess host quality before settling 210 irrevocably in a single location (Ward 1987). In such organisms, the success of newly-hatched 211 juveniles thus depends upon the quality of their natal host or being dispersed to a new suitable 212 host.

213 Our results showed that $A$. tsugae crawlers could discriminate between $F$. externa-infested

214 foliage at the shoot level (choice tests) and at the needle level (field survey). In the laboratory, $21568 \%$ of the choice tests had more $A$. tsugae crawlers on uninfested foliage than on F. externa216 infested foliage from $F$. externa naturally-infested trees. This preference was particularly evident 217 in choice tests conducted on experimentally infested trees, with a known prior history of no 218 infestation, where on average approximately twice as many $A$. tsugae crawlers showed 219 preference for uninfested foliage. In the field, the co-occurrence of $A$. tsugae and F. externa on 220 the same needle occurred $42 \%$ less often than expected if both insects were randomly distributed 221 with respect to each other. Because F. externa crawlers settle on the surveyed newly-produced 222 foliage earlier in the summer than $A$. tsugae crawlers, the most likely explanation for our results 223 is that the presence of settled F. externa drives A. tsugae preference and settlement through 224 plant-mediated changes in foliage quality. The possibility of apparent competition can also be 225 ruled out since $A$. tsugae has no efficient predators in the invaded range or parasitoids worldwide 226 (Wallace \& Hain, 2000; Havill et al., 2011).

227 Our results showed that $A$. tsugae has a lower preference for $F$. externa-infested shoot 228 regardless of the number of $F$. externa present on the infested shoot. This suggests that the 229 foraging cue $A$. tsugae uses to avoid $F$. externa is not density-dependent. Instead, a 
230 presence/absence cue might be used as a longer-range detection mechanism to identify (and

231 subsequently avoid) a broader tree area infested with $F$. externa. This is advantageous because in

232 tree hosts where $F$. externa density is not high, their distribution is initially very patchy within

233 the tree (Preisser, unpublished data). Although we found that A. tsugae has a lower preference

234 for F. externa-infested foliage, we still observed co-occurrence in the field and especially in the

235 laboratory choice-tests. One possible explanation is that $A$. tsugae has not yet adapted to avoid $F$.

236 externa-infested foliage to a larger extent. While $A$. tsugae invaded New England in the late

237 1980s (McClure \& Cheah, 1999), the rapid spread of F. externa through this area began in the

238 early 2000s (Preisser et al., 2008); as a result, the co-occurrence of high-density populations of

239 both species is a relatively new event. It is also possible that while $A$. tsugae prefers to settle on

$240 F$. externa-free foliage, it will settle in a suboptimal location rather than incur the risk of

241 increased mortality associated with continued searching for a feeding location.

242 The fact that $A$. tsugae is obligately asexual in its invaded range (McClure, 1987) might

243 constrain selection for $F$. externa avoidance; since all offspring are clones of their parent, the

244 only source of genetic variation is randomly-occurring mutations in a given individual. The lack

245 of sexual reproduction, and the recombination that results, might limit the adelgid's ability to

246 adapt to avoid a competing herbivore. Despite this limitation, there is some evidence that

247 adelgids in the invaded range have differentiated in response to strong selection; specifically,

248 northern adelgid clones are more tolerant to cold winter temperatures than their southern

249 counterparts (Butin et al., 2005). The authors of this paper suggest that the extremely high rates

250 of adelgid fecundity - a single female can produce $>300$ eggs in one generation - might produce

251 so many individuals that even 'rare' random mutations could often occur. If avoiding F. externa

252 foliage increases $A$. tsugae fitness, as suggested by higher $A$. tsugae population growth rate on 
253 uninfested versus F. externa-infested trees (Miller-Pierce \& Preisser, 2012), mutations that

254 promote $F$. externa avoidance (or quality discrimination in general) could provide a substantial 255 fitness advantage to the clonal line.

256 Despite being the more recent invader in New England, F. externa has now exceeded the 257 northern range of $A$. tsugae and is present in areas that currently lack the adelgid. If $F$. externa 258 can lower A. tsugae densities (Miller-Pierce \& Preisser, 2012), and therefore tree mortality 259 (Preisser et al., 2008), hemlock stands previously colonized by F. externa might derive some 260 benefit from the presence of this second invasive herbivore. Alternately, the ability of $A$. tsugae 261 to efficiently discriminate against $F$. externa-infested foliage within a host might minimize the 262 potential benefits of $F$. externa infestation. Future research should investigate what herbivore 263 induced plant-mediated traits influence within-host feeding site selection and whether they are 264 similar in response to hetero- and conspecific herbivores.

265

266

267

268

269

270

271

272

273

274 275

\section{Acknowledgements}

The authors thank L. Glidden for practical assistance during preliminary experiments, C. Thornber for statistical advice, landowners for granting permission to survey the trees used in the field study and two anonymous reviewers for useful comments on the manuscript. This project was funded by NSF DEB-0715504 and NIFA 2011-67013-30142 to ELP.

\section{Contribution of authors}

SG designed the project with intellectual contributions from all authors, SG and LGK collected and analyzed the data and all authors contributed to the writing of the manuscript. 


\section{References}

277

278

279

280

281

282

283

284

285

286

287

288

289

290

291

292

293

294

295

296

297

298

Abell, K.J. (2010) Population dynamics and biological control of elongate hemlock scale, Fiorinia externa. PhD thesis. University of Massachusetts Amherst, MA, USA.

Anderson, P. \& Agrell, J. (2005) Within-plant variation in induced defence in developing leaves of cotton plants. Oecologia, 144, 427-434.

Awmack, C.S. \& Leather, S.R. (2002) Host plant quality and fecundity in herbivorous insects. Annual Review of Entomology, 47, 817-844.

Burstein, M. \& Wool, D. (1993) Gall aphids do not select optimal galling sites (smynthurodesbetae, pemphigidae). Ecological Entomology, 18, 155-164.

Butin, E., Porter, A.H. \& Elkinton, J. (2005) Adaptation during biological invasions and the case of Adelges tsugae. Evolutionary Ecology Research, 7, 887-900.

Cobb, R.C. (2010) Species shift drives decomposition rates following invasion by hemlock woolly adelgid. Oikos, 119, 1291-1298.

Coley, P.D. \& Barone, J.A. (1996) Herbivory and plant defenses in tropical forests. Annual Review of Ecology and Systematics, 27, 305-335.

Cronin, J.T. \& Abrahamson, W.G. (1999) Host-plant genotype and of her herbivores influence goldenrod stem galler preference and performance. Oecologia, 121, 392-404.

Evans, A.M. \& Gregoire, T.G. (2007) The tree crown distribution of hemlock woolly adelgid, Adelges tsugae (Hem., Adelgidae) from randomized branch sampling. Journal of Applied Entomology, 131, 26-33.

Fenner, M., Hanley, M.E. \& Lawrence, R. (1999) Comparison of seedling and adult palatability in annual and perennial plants. Functional Ecology, 13, 546-551. 
299 Gómez, S., Orians, C.M. \& Preisser, E.L. (2012) Exotic herbivores on a shared native host:

300 Tissue quality after individual, simultaneous, and sequential attack. Oecologia, 169, 1015$301 \quad 1024$.

302 Gómez, S., van Dijk, W. \& Stuefer, J.F. (2010) Timing of induced resistance in a clonal plant 303 network. Plant Biology, 12, 512-517.

Gómez, S., Onoda, Y., Ossipov, V. \& Stuefer, J.F. (2008) Systemic induced resistance: A risk305 spreading strategy in clonal plant networks? New Phytologist, 179, 1142-1153.

Gómez, S., Latzel, V., Verhulst, Y.M. \& Stuefer, J.F. (2007) Costs and benefits of induced resistance in a clonal plant network. Oecologia, 153, 921-930.

308 309

Gonda-King, L., Radville, L. \& Preisser, E.L. (2012) False ring formation in eastern hemlock branches: Impacts of hemlock woolly adelgid and elongate hemlock scale. Environmental Entomology, 41, 523-531.

Gripenberg, S., Mayhew, P.J., Parnell, M. \& Roslin, T. (2010) A meta-analysis of preferenceperformance relationships in phytophagous insects. Ecology Letters, 13, 383-393.

Havill, N., Montgomery, M.E. \& Keenan, M. (2011) Hemlock woolly adelgid and its hemlock hosts: a global perspective. Implementation and status of biological control of the hemlock woolly adelgid, Morgantown, WV, U.S. Forest Service.

Horner, J.D. \& Abrahamson, W.G. (1992) Influence of plant genotype and environment on oviposition preference and offspring survival in a gallmaking herbivore. Oecologia, 90, 323332.

Inbar, M., Doostdar, H., Leibee, G.L. \& Mayer, R.T. (1999) The role of plant rapidly induced responses in asymmetric interspecific interactions among insect herbivores. Journal of Chemical Ecology, 25, 1961-1979. 
322 Itioka, T. \& Inoue, T. (1991) Settling-site selection and survival of 2 scale insects, Ceroplastes

323 rubens and C. ceriferus, on citrus trees. Researches on Population Ecology, 33, 69-85.

324

325

326

327

328

329

330

331

332

333

334

335

336

337

338

339

340

341

342

343

344

345

Jenkins, J.C., Aber, J.D. \& Canham, C.D. (1999) Hemlock woolly adelgid impacts on community structure and $\mathrm{N}$ cycling rates in eastern hemlock forests. Canadian Journal of Forest Research-Revue Canadienne De Recherche Forestiere, 29, 630-645.

Karban, R. \& Baldwin, I.T. (1997) Induced Responses to Herbivory, Chicago, University of Chicago Press.

Kleine, S. \& Mueller, C. (2011) Intraspecific plant chemical diversity and its relation to herbivory. Oecologia, 166, 175-186.

Mattson, W.J. (1980) Herbivory in relation to plant nitrogen content. Annual Review of Ecology and Systematics, 11, 119-161.

McAuslane, H.J. \& Alborn, H.T. (2000) Influence of previous herbivory on behavior and development of Spodoptera exigua larvae on glanded and glandless cotton. Entomologia Experimentalis et Applicata, 97, 283-291.

McClure, M.S. (1991) Density-dependent feedback and population-cycles in Adelges tsugae (Homoptera, Adelgidae) on Tsuga canadensis. Environmental Entomology, 20, 258-264.

McClure, M.S. (1989) Evidence of a polymorphic life-cycle in the hemlock woolly adelgid, Adelges tsugae (Homoptera, Adelgidae). Annals of the Entomological Society of America, 82, $50-54$.

McClure, M.S. (1987) Biology and control of hemlock woolly adelgid. Connecticut Agricultural Experiment Station Bulletin (New Haven), 851, 1-9.

McClure, M.S. (1980) Foliar nitrogen - a basis for host suitability for elongate hemlock scale, Fiorinia externa (Homoptera, Diaspididae). Ecology, 61, 72-79. 
346

347

348

349

350

McClure, M.S. \& Cheah, C.A.S.-. (1999) Reshaping the ecology of invading populations of hemlock woolly adelgid, Adelges tsugae (Homoptera: Adelgidae), in eastern North America. Biological Invasions, 1, 247-254.

Miller-Pierce, M.R., Orwig, D.A. \& Preisser, E. (2010) Effects of hemlock woolly adelgid and elongate hemlock scale on eastern hemlock growth and foliar chemistry. Environmental Entomology, 39, 513-519.

Miller-Pierce, M.R. \& Preisser, E.L. (2012) Asymmetric priority effects influence the success of invasive forest insects. Ecological Entomology, 37, 350-358.

Nyman, T., Paajanen, R., Heiska, S. \& Julkunen-Tiitto, R. (2011) Preference-performance relationship in the gall midge Rabdophaga rosaria: Insights from a common-garden experiment with nine willow clones. Ecological Entomology, 36, 200-211.

Morin, R.S., Oswalt, S.N., Trotter, R.T. III \& Liebhold, A.M. (2011) Status of hemlock in the eastern United States. Forest inventory and analysis factsheet, e-Science update SRS-038. Asheville, NC. US Department of Agriculture Forest Service, Southern Research Station.

Orwig, D.A., Thompson, J.R., Povak, N.A., Manner, M., Niebyl, D. \& Foster, D.R. (2012) A foundation tree at the precipice: Tsuga canadensis health after the arrival of Adelges tsugae in central New England. Ecosphere, 3, 10

Orwig, D.A. \& Foster, D.R. (1998) Forest response to the introduced hemlock woolly adelgid in southern New England, USA. Journal of the Torrey Botanical Society, 125, 60-63.

Preisser, E.L. \& Elkinton, J.S. (2008) Exploitative competition between invasive herbivores benefits a native host plant. Ecology, 89, 2671-2677.

Preisser, E.L., Lodge, A.G., Orwig, D.A. \& Elkinton, J.S. (2008) Range expansion and population dynamics of co-occurring invasive herbivores. Biological Invasions, 10, 201-213. 
369 Preisser, E.L., Miller-Pierce, M.R., Vansant, J. \& Orwig, D.A. (2011) Eastern hemlock (Tsuga

370

371

372

373

374

375

376

377

378

379

380

381

382

383

384

385

386

387

388

389

canadensis) regeneration in the presence of hemlock woolly adelgid (Adelges tsugae) and elongate hemlock scale (Fiorinia externa). Canadian Journal of Forest Research-Revue Canadienne De Recherche Forestiere, 41, 2433-2439.

Radville, L., Chaves, A. \& Preisser, E.L. (2011) Variation in plant defense against invasive herbivores: Evidence for a hypersensitive response in eastern hemlocks (Tsuga canadensis). Journal of Chemical Ecology, 37, 592-597.

Shelton, A.L. (2004) Variation in chemical defences of plants may improve the effectiveness of defence. Evolutionary Ecology Research, 6, 709-726.

Soler, R., Pineda, A., Li, Y., Ponzio, C., van Loon, J.J.A., Weldegergis, B.T. \& Dicke, M. (2012) Neonates know better than their mothers when selecting a host plant. Oikos, 121, 19231934.

Soler, R., Bezemer, T.M., Cortesero, A.M., Van der Putten, W.H., Vet, L.E.M. \& Harvey, J.A. (2007) Impact of foliar herbivory on the development of a root-feeding insect and its parasitoid. Oecologia, 152, 257-264.

Stadler, B., Muller, T., Orwig, D. \& Cobb, R. (2005) Hemlock woolly adelgid in New England forests: Canopy impacts transforming ecosystem processes and landscapes. Ecosystems, 8, 233-247.

Thompson, J.N. (1988) Evolutionary ecology of the relationship between oviposition preference and performance of offspring in phytophagous insects. Entomologia Experimentalis et Applicata, 47, 3-14. 
390 Turner, J.L., Fitzpatrick, M.C. \& Preisser, E.L. (2011) Simulating the dispersal of hemlock 391 woolly adelgid in the temperate forest understory. Entomologia Experimentalis et Applicata, $392 \quad 141,216-223$.

393 Underwood, N. (2012) When herbivores come back: effects of repeated damage on induced $394 \quad$ resistance. Functional Ecology, 26, 1441-1449.

395 van Leur, H., Vet, L.E.M., Van der Putten, W.H. \& van Dam, N.M. (2008) Barbarea vulgaris 396 glucosinolate phenotypes differentially affect performance and preference of two different 397 species of lepidopteran herbivores. Journal of Chemical Ecology, 34, 121-131.

398 Wallace, M.S. \& Hain, F.P. (2000) Field surveys and evaluation of native and established 399 predators of the hemlock woolly adelgid (Homoptera : Adelgidae) in the southeastern united $400 \quad$ states. Environmental Entomology, 29, 638-644.

401 Ward, S.A. (1987) Optimal habitat selection in time-limited dispersers. American Naturalist, $402 \quad 129,568-579$.

403 Young, R.F., Shields, K.S. \& Berlyn, G.P. (1995) Hemlock woolly adelgid (Homoptera, 404 Adelgidae) - stylet bundle insertion and feeding sites. Annals of the Entomological Society $405 \quad$ of America, 88, 827-835. 


\section{Figure Legends}

Figure 1. (a) Percentage of choice tests with the majority of $A$. tsugae crawlers on uninfested foliage (white) or F. externa-infested foliage (gray); (b) Typical choice test experimental set-up; (c) Frequency distribution of choice tests with different ranges of $A$. tsugae crawler percentage on uninfested foliage; (d) Correlation between A. tsugae crawlers on F. externa-infested foliage and number of $F$. externa present on the infested foliage.

Figure 2. Average number (+ standard error) of A. tsugae crawlers on uninfested (white) or F. externainfested (gray) foliage sampled from manually inoculated trees in laboratory dual choice tests. F. externa was left intact on the foliage in a subset of choice tests (left bars; $n=30$ ) and it was manually removed from the infested foliage in a second subset (right bars; $n=32$ ). 


\section{Figure 1}

(a)

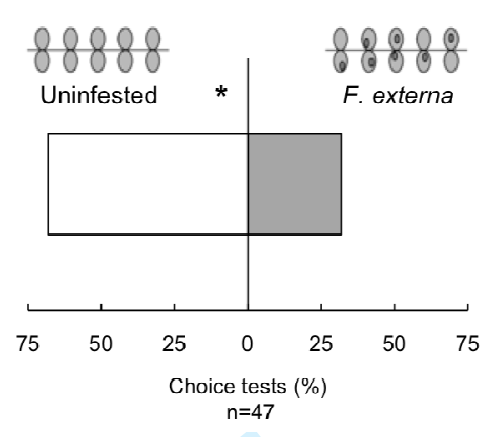

(c)

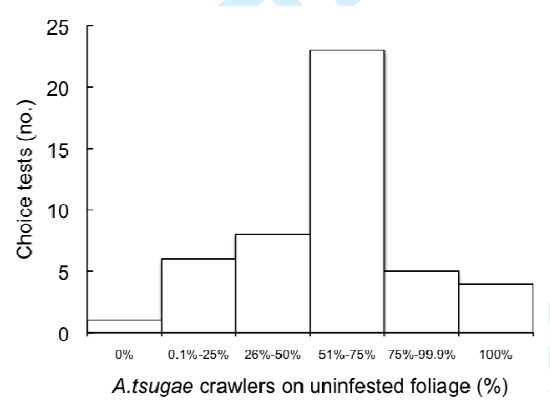

(b)

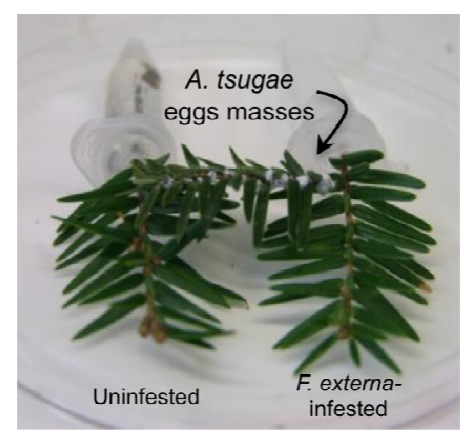

(d)

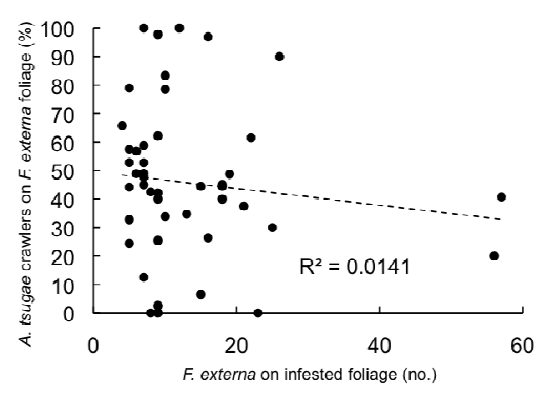


Figure 2

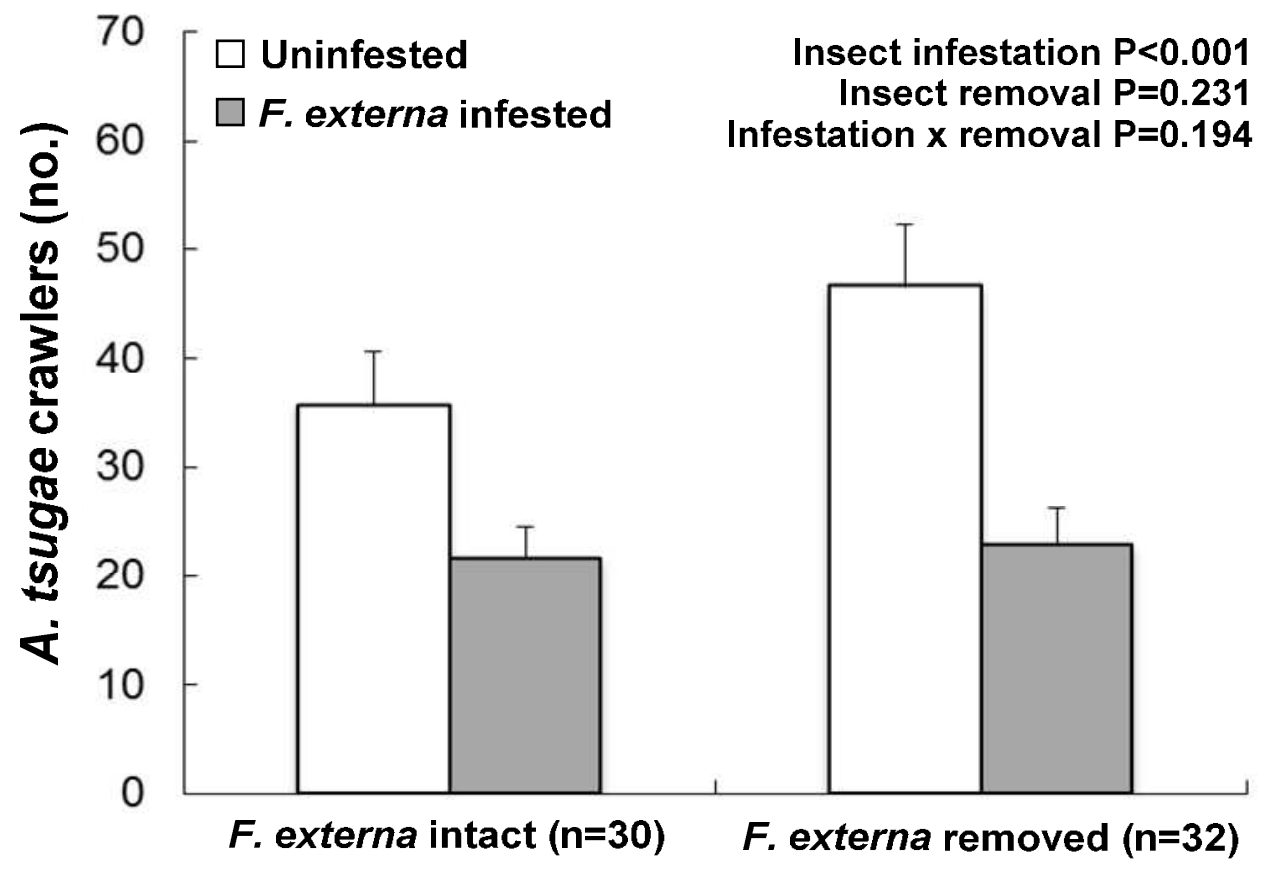


Table 1. Observed counts of $A$. tsugae and F. externa on individual needles of eastern hemlock naturally occurring in the field. Numbers in brackets represent the expected values.

\begin{tabular}{|c|c|c|c|}
\hline & \multicolumn{2}{|c|}{ A. tsugae } \\
\hline & & Absent & Present \\
\hline$\frac{\mathbb{Q}}{\delta}$ & 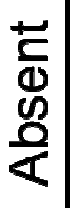 & $\begin{array}{c}1556 \\
(1586)\end{array}$ & $\begin{array}{c}339 \\
(308)\end{array}$ \\
\hline $\begin{array}{l}\text { (1) } \\
\text { டு }\end{array}$ & 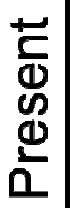 & $\begin{array}{c}408 \\
(377)\end{array}$ & $\begin{array}{c}43 \\
(73)\end{array}$ \\
\hline
\end{tabular}

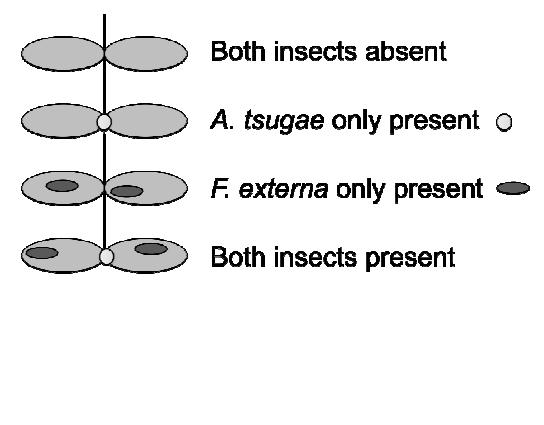

